\title{
THE NON-PROTEIN CONSTITUENTS OF THE PLASMA IN MYELOMATOSIS
}

\author{
BY \\ N. H. MARTIN AND H. SCULTHORPE \\ From the Department of Chemical Pathology, St. George's Hospital Medical School, London
}

(RECEIVED FOR PUBLICATION MARCH 7, 1958)

Myelomatosis, a disease associated primarily with a defect in protein metabolism, may on occasion produce other bizarre and even misleading changes in the plasma constituents.

Isolated reports of unusual cases, such as those of Cantarow in 1935 and Nassim and Crawford in 1950, have appeared from time to time in the literature ; but more comprehensive reviews show such a divergence of opinion on the frequency with which these abnormal "ancillary" biochemical findings occur that it seemed of practical value to give in condensed form the analysis on 74 proved cases of myelomatosis examined and followed in this department in the course of a much wider study of the causes and significance of hyperglobulinaemia.

The histograms refer to the levels found in the first samples submitted to the laboratory from each patient. To have grouped all the analyses carried out would, we believe, have given an artificial picture, for it is natural that unusual values have been repeated more often than normal values; moreover, "terminal" values, except in the rare instances when patients were admitted undiagnosed in extremis, are not of great practical value. Of greater interest are the bizarre findings encountered when the patient first comes to the doctor.

\section{Methods}

Total Protein.-This was estimated as total nitrogen by the micro-Kjeldahl distillation technique of Pregl, and, after subtraction of the non-protein nitrogen, converted to protein using a factor of 6.25 .

Urea.-Urea was estimated by a modification (Harrison, 1947) of the urease-Nesslerization method of Archer and Robb (1925).

Uric Acid.- The estimation was carried out by the method of Brown (1945), which gives values not more than $0.2 \mathrm{mg}$. above the true uric acid levels except in renal damage.

Cholesterol.-Cholesterol was estimated using the Liebermann-Burchardt reaction by a modification of the methods of Bloor (1928) or Sackett (1925). The estimation was carried out on $1 \mathrm{ml}$. of serum.

Alkaline Phosphatase.-This was estimated by determining the liberated phenol from diphenyl phosphate with Folin and Ciocalteau's phenol reagent, using the micro-method of King and Armstrong (King, 1956).

One Bodansky unit is approximately equal to $2 \frac{1}{2}$ King-Armstrong units.

Calcium.-Calcium was estimated by direct precipitation from serum as calcium oxalate, and titration of the washed precipitate dissolved in acid, with standard permanganate solution by the method of Kramer and Tisdall as modified by Clark and Collip (1925).

Inorganic Phosphorus.-This was estimated by the method of Fiske and Subbarow (1925) using 1.2.4. aminonaphtholsulphonic acid as the reducing agent.

\section{Results}

The total proteins are shown in the form of a histogram (Fig. 1) and call for no special comment except to stress that of 74 analyses 26 fell within or below the normal limits.

The histogram (Fig. 2) for the urea levels indicates that $12 \%$ of patients had blood urea levels

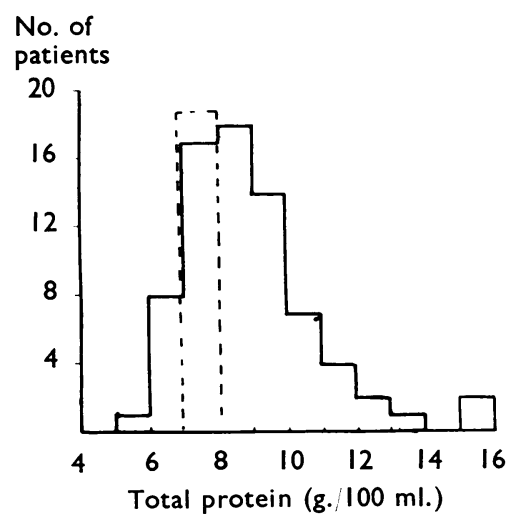

FIG. 1.-Values for total protein (frame $=97 \%$ normal levels). 


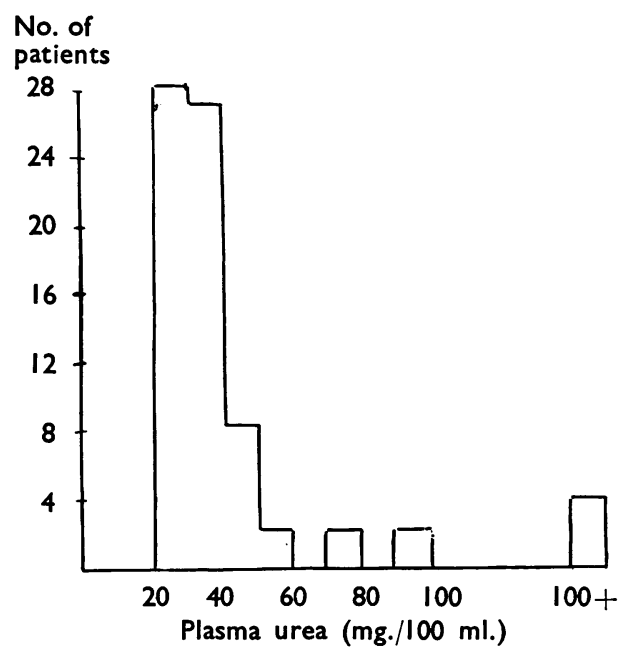

Fig. 2.-Plasma urea concentrations.

above the normally accepted upper limits of 47 $\mathrm{mg}$. for $100 \mathrm{ml}$. Of the patients with a blood urea over 100 , two were admitted with advanced renal failure, the diagnosis of myelomatosis being unsuspected at the time of admission.

Calcium Levels.-Twenty-two per cent. were above the limits of normal, and $10 \%$ below normal limits (Fig. 3). The latter all had

No. of

patients

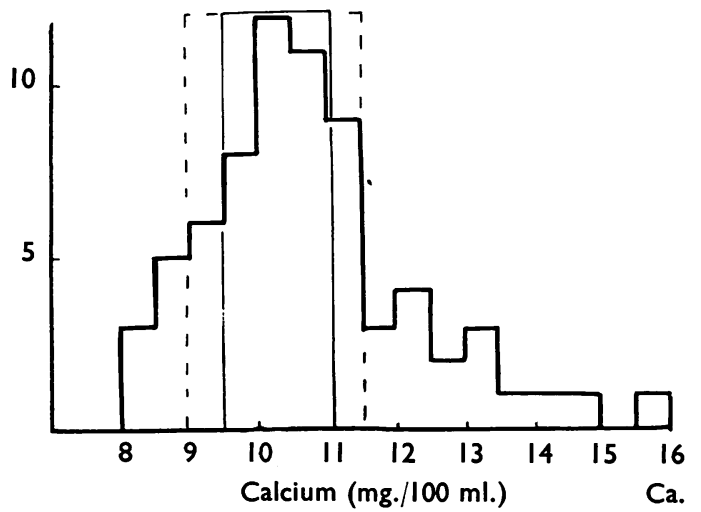

FIG. 3.-Calcium levels (outer frame, - $-99 \%$ normal; inner fram :, - $90 \%$ normal).

unequivocal evidence of renal damage. Table I shows the maximum variations in calcium levels observed in five patients on whom serial studies were made with the time interval beween the two readings.

Phosphorus Levels.-Seventeen per cent. fell above upper normal limits, while no levels were
TABLE J

MAXIMAL OBSERVED VARIATIONS IN CALCIUM LEVELS IN FIVE PATIENTS

\begin{tabular}{c|c|c|c}
\hline $\begin{array}{c}\text { Code } \\
\text { No. in } \\
\text { Series }\end{array}$ & $\begin{array}{c}\text { First } \\
\text { Observation } \\
\text { (mg./100 ml.) }\end{array}$ & $\begin{array}{c}\text { Second } \\
\text { Observation } \\
\text { (mg./100 ml.) }\end{array}$ & $\begin{array}{c}\text { Time Lapse } \\
\text { Between } \\
\text { Observations } \\
\text { in Months }\end{array}$ \\
\hline 8 & 9.0 & 11.0 & 6 \\
4 & 11.8 & 13.2 & 4 \\
25 & 9.6 & 10.6 & 8 \\
38 & 9.4 & 8.2 & 3 \\
43 & 14.0 & 9.1 & 10 \\
\hline
\end{tabular}

recorded below $2 \mathrm{mg} . / 100 \mathrm{ml}$.; $33 \%$ had $\mathbf{P}$ levels above $4 \mathrm{mg}$. $/ 100 \mathrm{ml}$. Of these, one, with a level of $12.7 \mathrm{mg} . / 100 \mathrm{ml}$., was in advanced renal failure. Table II shows renal clearance values on eight patients with values for serum inorganic phosphorus and uric acid obtained at the time the clearance was done.

No. of

patients

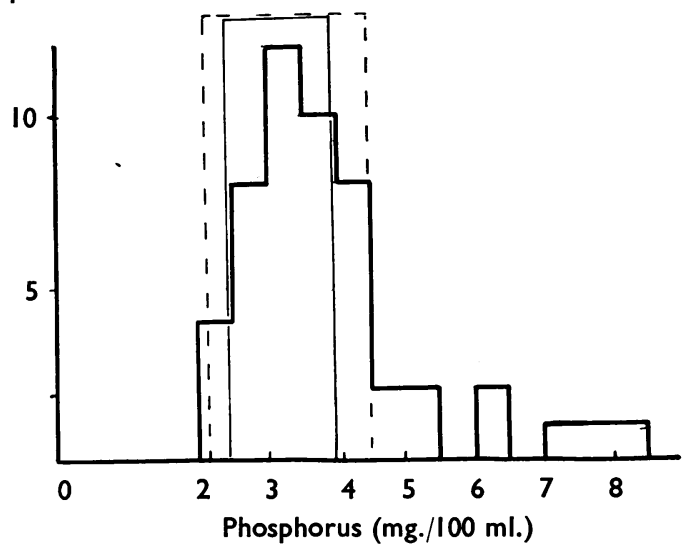

FIG. 4.-Phosphorus levels (outer frame, - - $99 \%$ normal; inner frame, $-90 \%$ normal).

TABLE II

UREA CLEARANCE VALUES WITH SYNCHRONOUS PHOSPHORUS, URIC ACID, AND TOTAL PROTEIN VALUES IN EIGHT CASES

\begin{tabular}{|c|c|c|c|c|c|c|}
\hline $\begin{array}{l}\text { Case } \\
\text { No. }\end{array}$ & $\mid \begin{array}{c}\text { Code } \\
\text { No. } \\
\text { in } \\
\text { Series }\end{array}$ & 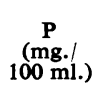 & $\begin{array}{c}\text { Uric } \\
\text { Acid } \\
\text { (mg./ } \\
100 \mathrm{ml} .)\end{array}$ & $\begin{array}{c}\text { Total } \\
\text { Protein } \\
(\mathrm{g} . / \\
100 \mathrm{ml} .)\end{array}$ & $\begin{array}{c}\text { Urea } \\
\text { (mg./ } \\
100 \mathrm{ml} . \text { ) }\end{array}$ & $\begin{array}{c}\text { Urea } \\
\text { Clear- } \\
\text { ance } \\
(\% \mathrm{~N})\end{array}$ \\
\hline $\begin{array}{l}1 \\
2 \\
3 \\
4 \\
5 \\
6 \\
7 \\
8\end{array}$ & $\begin{array}{l}38 \\
34 \\
72 \\
1 \\
62 \\
67 \\
44 \\
33\end{array}$ & $\begin{array}{r}2.8 \\
3.5 \\
3.0 \\
2.6 \\
3.2 \\
6.5 \\
8.7 \\
12.7\end{array}$ & $\begin{array}{l}6.6 \\
5.4 \\
7.0 \\
5.6 \\
6.2 \\
8.4 \\
5.4 \\
6.0\end{array}$ & $\begin{array}{r}11.3 \\
11.4 \\
8.6 \\
8.4 \\
8.7 \\
7.2 \\
6.7 \\
9.5\end{array}$ & $\begin{array}{r}31 \\
21 \\
50 \\
100 \\
220 \\
305 \\
170 \\
400\end{array}$ & $\begin{array}{c}80 \\
80 \\
76 \\
60 \\
45 \\
30 \\
20 \\
8.5\end{array}$ \\
\hline
\end{tabular}

Alkaline Phosphatase Levels. - These were recorded in King-Armstrong units. Of 73 consecutive primary analyses, only one exceeded the absolute upper limits of our normal adult range 
and only three fell outside the usually accepted limits (Fig. 5).

Maximal individual fluctuations from follow-up data on five patients are shown in Table III with the time interval between the observations.

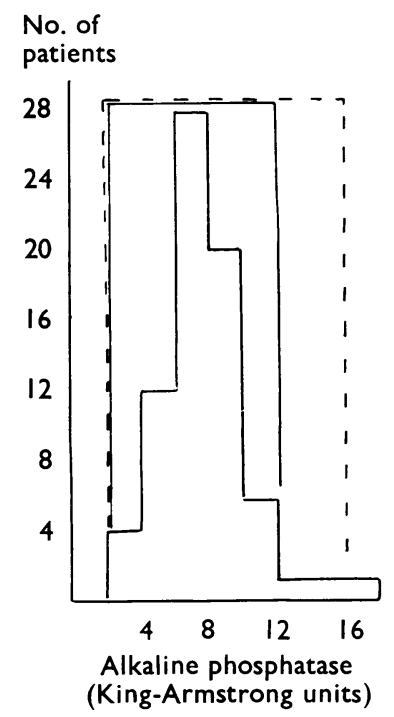

Fig. 5.-Alkaline phosphatase levels (outer frame, - - $-99 \%$ normal; inner frame, _- $90 \%$ normal).

TABLE III

VARIATIONS IN ALKALINE PHOSPHATASE

\begin{tabular}{c|c|c|c|c}
\hline $\begin{array}{c}\text { Case } \\
\text { No. }\end{array}$ & $\begin{array}{c}\text { Code } \\
\text { No.in } \\
\text { Series }\end{array}$ & $\begin{array}{c}\text { First } \\
\text { Observation }\end{array}$ & $\begin{array}{c}\text { Second } \\
\text { Observation }\end{array}$ & $\begin{array}{c}\text { Time Lapse } \\
\text { Between } \\
\text { Observations } \\
\text { in Months }\end{array}$ \\
\hline 1 & 4 & $8 \cdot 3$ & $15 \cdot 7$ & 6 \\
2 & 7 & $6 \cdot 0$ & $8 \cdot 5$ & 12 \\
3 & 38 & $8 \cdot 0$ & $12 \cdot 0$ & 15 \\
4 & 39 & $13 \cdot 0$ & $8 \cdot 0$ & 6 \\
5 & 34 & 6.0 & $3 \cdot 0$ & 36 \\
\hline
\end{tabular}

There was no precise relation between the extent of bone involvement as judged radiologically and the phosphatase levels.

Fig. 6 shows initial plasma uric acid levels of 18 patients ; eight were above the upper normal limit, and, though the highest levels observed were in a patient with a considerable degree of associated

No. of

patients

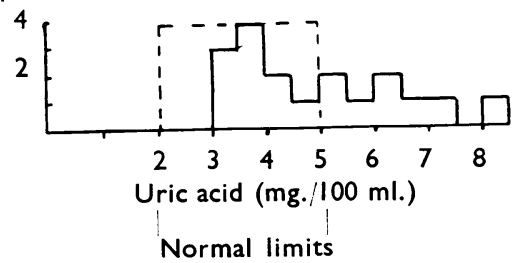

FIG. 6.-Plasma uric acid concentrations. renal damage (see Table II), uric acid levels were above normal in four patients in which there is no clear evidence of renal damage, and of the 18 analyses only two were below the mean of the normal span.

Cholesterol Levels. - These were analysed in 20 patients. Two were above the upper normal limit of $250 \mathrm{mg} . / 100 \mathrm{ml}$. One of these was a diabetic of six years' standing.

\section{Discussion}

It might be expected that the widespread use of electrophoretic technique, and the bizarre protein pattern it discloses in more than $80 \%$ of patients with myelomatosis, would help to establish the diagnosis with greater confidence at an earlier stage in the course of disease. We are not convinced, from a plot of the age incidence of the present series (Fig. 7), that it has materially altered the age at which the diagnosis is established.

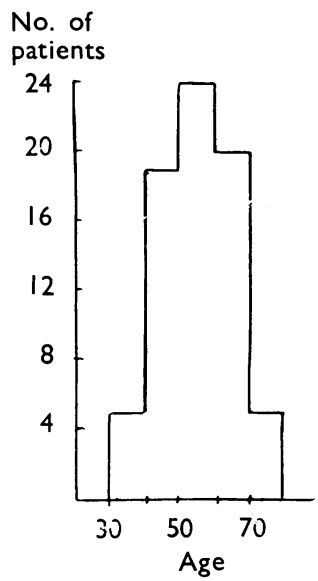

FIG. 7.-Age distribution.

The majority of comprehensive reviews give the incidence of renal impairment as ranging from $50 \%$ to $86 \%$ of all cases, but do not say at what stage of the disease the assessments were made. However, if a blood urea level above $47 \mathrm{mg}$./100 $\mathrm{ml}$. be taken as suggestive of renal impairment, only 10 out of 70 patients appeared to have renal impairment when first seen. Two of the patients in the present series were admitted with advanced renal failure, the diagnosis of myelomatosis only being made after admission. There is no doubt that at necropsy a high percentage of patients suffering from myelomatosis would show some renal lesions.

The reported incidence of a significantly raised serum calcium level varies from 28 out of 41 
patients examined and reported on by Bayrd and Heck (1947), to 18 out of 35 reported by Lichtenstein and Jaffe (1947). Adams, Alling, and Lawrence (1949) found 24 out of 45 cases had calcium levels above $12 \mathrm{mg} . / 100 \mathrm{ml}$., while Snapper, Turner, and Moscovitz (1953) report 30 out of 80 cases studied with a serum calcium level above $12 \mathrm{mg}$. $/ 100 \mathrm{ml}$. In the present series, 13 out of 70 patients had blood calcium levels above 12 mg./100 ml. when first examined. The highest calcium level we have found was $17.0 \mathrm{mg} . / 100 \mathrm{ml}$., though much higher levels are recorded in the literature, up to $18.8 \mathrm{mg}$. $/ 100 \mathrm{ml}$. by Robbins and Kydd (1935) and $20 \mathrm{mg} . / 100 \mathrm{ml}$. by Schittenhelm (1929). Cantarow, in 1935, described a patient whose blood calcium fluctuated between $12.9 \mathrm{mg}$. and $9.2 \mathrm{mg} . / 100 \mathrm{ml}$. We have only seen one instance of a fluctuation as great as this in a patient suffering from progressive renal failure, though lesser fluctuations are common.

Unlike patients with active parathyroid adenoma, the serum inorganic phosphorus levels were never below $2 \mathrm{mg}$. $/ 100 \mathrm{ml}$. Indeed, only four out of 51 initial analyses were below $2.5 \mathrm{mg}$./ $100 \mathrm{ml}$. and at no stage in the condition have we recorded a value below $2.2 \mathrm{mg}$. $/ 100 \mathrm{ml}$.

At initial examination when less than $15 \%$ of the present series had blood urea levels suggestive of some renal damage, $33 \%$ had levels of serum inorganic phosphorus above $4 \mathrm{mg} . / 100 \mathrm{ml}$., suggesting that the raised phosphorus levels often seen in myelomatosis are not the result of renal damage alone.

It is tempting to imagine that they are related to the increased turnover of nucleoprotein and to couple the observation with the relatively high plasma uric acids commonly recorded. Table II shows that three patients of the present series had uric acid levels of $5.4,6.6$, and $7 \mathrm{mg} . / 100 \mathrm{ml}$. respectively at a time when urea clearance studies suggested an adequate renal function. The levels of uric acid do not show any relation to levels of circulating proteins.

There is little agreement in the literature on the levels of alkaline phosphatase. Bayrd and Heck (1947), in a study of 24 cases, record levels of between 0.8 and 12 Bodansky units, stating that the upper limit of normal would be four Bodansky units. Adams et al. (1949), recording the results from 22 patients, found 10 with values above 4 Bodansky units.

In contrast Snapper et al. (1953) found only 15 out of 86 patients with serum alkaline phosphatase levels above $12 \mathrm{King}$-Armstrong units. In the present series only four out of 73 had alkaline phosphatase levels above 12 King-Armstrong units, and only one above 16 King-Armstrong units. We have never examined a patient who at any stage in the progress of the disease had an alkaline phosphatase level above 30 KingArmstrong units, and we consider that a raised alkaline phosphatase is strong presumptive evidence, whatever the radiological appearances, against uncomplicated myelomatosis.

\section{Summary}

The initial biochemical findings in 74 consecutive patients, subsequently proved to have myelomatosis, are presented.

Thirteen of these patients had calcium levels above $12 \mathrm{mg}$. per $100 \mathrm{ml}$. serum, but in none of these was the serum inorganic phosphorus level below $2.5 \mathrm{mg}$. per $100 \mathrm{ml}$. serum.

In 73 out of 74 patients the serum alkaline phosphatase level was within normal limits. It is suggested that to find a markedly raised alkaline phosphatase level is strong presumptive evidence that the patient is not suffering from uncomplicated myelomatosis.

The use of modern methods of protein analysis, while they have helped to establish the diagnosis, have not materially altered the age incidence at which the diagnosis is made.

Our thanks are due to the numerous physicians and pathologists, especially the staff of St. George's Hospital, for the opportunity to examine the patients and make the chemical analysis.

We wish to acknowledge the support of the British Empire Cancer Campaign for defraying part of the expense of this investigation.

\section{REFERENCES}

Adams, W. S., Alling, E. L., and Lawrence, J. S. (1949). Amer. J. Med., 6, 141 .

Archer, H. E., and Robb, G. D. (1925). Quart. J. Med., 18, 274. Bayrd, E. D., and Heck, F. J. (1947). J. Amer. med. Ass., 133, 147. Bloor, W. R. (1928). J. biol. Chem., T7, 53.

Brown, H. (1945). Ibid., 158, 601.

Cantarow, A. (1935). Amer. J. med. Sci., 189, 425

Clark, E. P., and Collip, J. B. (1925). J. biol. Chem., 63, 461.

Fiske, C. H., and Subbarow, Y. (1925). Ibid., 66, 375.

Harrison, G. A. (1947). Chemical Methods in Clinical Medicine, 3rd ed. J. and A. Churchill, London.

King, E. J. (1956). Micro-Analysis in Medical Biochemistry, 3rd ed. Churchill, London.

Lichtenstein, L., and Jaffe, H. L. (1947). Arch. Path. (Chicago), 44, 207.

Nassim, J. R., and Crawford, T. (1950). Brit. J. Surg., 37, 287. Robbins, C. L., and Kydd, D. M. (1935). J. clin. Invest., 14, 220.

Sackett, G. E. (1925). J. biol. Chem., 64, 203.

Schittenhelm, A. (1929). Dtsch. med. Wschr., 55, 508.

Snapper, I., Turner, L. B., and Moscovitz, H. L. (1953). Multiple Myeloma. Grune \& Stratton, New York.
apper, I., Turner, L. B., and Moscovitz, H. 